\section{Losing representation}

The council of the International Union of Geodesy and Geophysics (IUGG) met in Durham recently. David Davies reports

IN a decision that seems to have been reached amid some concern about the politicisation of international nongovernmental scientific organisations, the Council of the IUGG at an extraordinary meeting held in Durham has voted $47-7$ to cancel the membership of Taiwan and to bring in the People's Republic of China. The vote is particularly important because it could open the way to much wider Chinese membership of international organisations, though presumably only at the price of much wider expulsion of Taiwan.

Last year the International Union of Geological Science meeting in Australia took a similar course, but the Australian government had not allowed Taiwanese representatives entry visas to state their case. In Durham Professor Y. B. Tsai spoke for Taiwan, but returned with a colleague to Taipei after the ratification of the decision, even though he was scheduled to speak at a subsequent scientific meeting.
The ballot was secret but there is no doubt that the UK and United States voted against. Both these countries stressed that they had no opposition at all to Peking's membership, but only to the preconditions. Indeed, the UK tried without success to get a motion considered which simply admitted Peking whilst taking no action on Taipei. In the event it was clear that many representatives had come with the firmest instructions from their governments or academies to admit Peking on its own terms. A few countries did not even send a scientist to vote for them but despatched an embassy official from London-a practice which the International Council of Scientific Unions would do well to look at as soon as possible.

In hindsight the haste with which the IUGG seems to have brought the matter to a head was probably unnecessary. The next IUGG assembly is planned for Australia in 1979 and it was thought at one time that Australia would refuse to support a meeting at which Taipei but not Peking was represented. But the Australian position has since softened somewhat and it is possible that the Taiwanese would have been admitted provided they did not claim to be official representatives.

The Taiwan position is difficult now, in spite of assurances that the Bureau of the IUGG will look after the interests of individuals and will ensure that appropriate information gets through. Many Durham delegates urged the Taiwanese to stay, to continue to attend meetings and to remain in the closest touch. But there is a political reason why this is unlikely. The motion that was passed did not simply call for a switch of membership -it pointedly went out of its way to explain the reason: that the "vast majority of countries" now recognise Taiwan to be a province of the People's Republic of China. The Taiwan government also claims that Taiwan is a province of China-but not, of course of the People's Republic. And the Academia Sinica of Taipei is on record as having claimed to speak only for scientists within its own shores. Thus any organisation which acknowledges de jure Peking rule over Taipei is unlikely to see Taiwanese citizens at its meetings in the forseeable future.

The whole sad affair, which gives the impression of having been pushed through for political convenience, will undoubtedly give people ideas about getting rid of other countries because their policies are disagreeable or their political base is weak.

\title{
Spending a packet
}

Wendy Barnaby reports from Stockholm on one aspect of Sweden's continuing nuclear debate

LAST March, the Swedish branch of the Friends of the Earth sent a letter to the Prime Minister complaining that a socalled study packet on energy, produced with government funds, was in fact propaganda for nuclear power. The letter provoked some interest. The state auditors delved a little into the financing of the agency distributing the packet, Centrala Driftledningen (CDL), a non profit-making body which promotes many-sided cooperation between the electricity companies, and which is half financed by the State Power Board. The Prime Minister, Thorbjörn Fälldin, replied that he had not known about the distribution of the packet, but that to control the agency's operations would conflict with democratic principles. A question was asked in parliament, but received only a vague answer from the Energy Minister. Then recently-just before the government was to approve the State Power Board's annual budget-rumours circulated that its normal contribution of about $\$ 865,000$ to CDL would be axed. In the event, the money was approved and the agency will be able to continue its normal operations.

The study packet was written by CDL and various organisations responsible for energy supplies. Meant for schools, study circles, trade unions, companies and so on, it consists of seven attractive booklets totalling 152 pages, as well as a 102-page book entitled Nuclear Energy: Principles and Problems written by a reactor physicist who works with the Atomic Energy Company. Describing the aims of the package, the distributors said that its facts should be correct and easily distinguishable from evaluations.

In some cases, this holds; often it does not. One of the booklets stresses, for example, that no increase in genetic defects has been found in the offspring of survivors of Hiroshima and Nagasaki. But for a public generally ignorant of the studies showing that the survivors have more than their share of medical complaints, the sus- picion arises that the authors are trying to minimise the effects of radiation. The same booklet also asserts that the risks of nuclear reactors are small, that the industry is subjected to stricter control than any other, and that the dangers of nuclear-weapon proliferation and terrorism have been exaggerated. In short, the publications, taken together, leave no doubt that the best available energy source is nuclear.

Following the news that CDL would be able to continue, its director, Bengt Sterne, commented: "It was a political question-it's all over now". Of course it was a political question. The President of Friends of the Earth, Lennart Daléus, agrees in principle that CDL should have its money, but says that, as it is the only organisation with enough money to give the public significant amounts of information, it should use government funds more responsibly. Certainly, the problem would be eased if both sides of the nuclear debate could compete on equal terms. It has long been a sore point with antinuclear groups that government support is so one-sided. A spokesman at the Department of Industry, which also deals with energy, says that at the moment there is no government fund- 
ing of anti-nuclear groups-although there is about $\$ 100,000$ in the pipeline for them. A proposal by the Liberal
Party that they should get an annual grant of about $\$ 22,000$ seems to have been dropped. Even if it had been adop- ted, total government spending would still have favoured the pro-nuclear groups by about eleven to one.

\section{NETHERLANDS}

-Mrs Vorrink, Holland's Minister of Public Health and Environmental Protection, plans to eliminate the presence of phosphates in detergents by 1985 , according to a report just published by the ministry and already agreed upon in a coordination-committee in which all departments take part. Partial or regional bans operate in Canada and the US; Germany plans to cut back the phosphate content in detergents to half the present level.

The problem is international, and in each country is caused partly by pollution from abroad. In the Netherlands more than half of the phosphates in the surface-waters is imported from other countries, and of the rest a good portion comes from detergents. The initiative to ban phosphates will help, but a more complete solution would require European action. Industry's assistance would also be necessary.

Before Mrs Vorrink reached the end of her ministerial appointmentshe is unlikely to return in the new government now in the process of formation-she concerned herself with the warning on spray cans which contain halocarbons. The warning mentions that they can have deleterious environmental effects. The minister's memorandum announces a ban on the use of the gases in spray cans. Industry protested immediately, saying that work for 700 people would be in danger and that the measures would be premature, as no scientific evidence was available that the ozone layer is broken down by halocarbons.

-The former Minister for Science Policy, Mr Trip, will not be part of a new government. What is more, his portfolio is said to be in danger, in spite of advice to the Prime Minister, $\mathrm{Mr}$ den Uyl. $\mathrm{He}$ has received two reports on improving the communication of information on science and technology to a larger public. One was compiled by two committees, in which scientists, science-information officers and science writers participated.

The product of 18 months' work, the report concluded that a central service for information on science should be created at the Royal Academy of Sciences, which should have a coordinating role. In the Netherlands all universities have their press- and information-offices; so too do most of the government research institutes. The position has improved in recent years, but gaps remain. Information is restricted

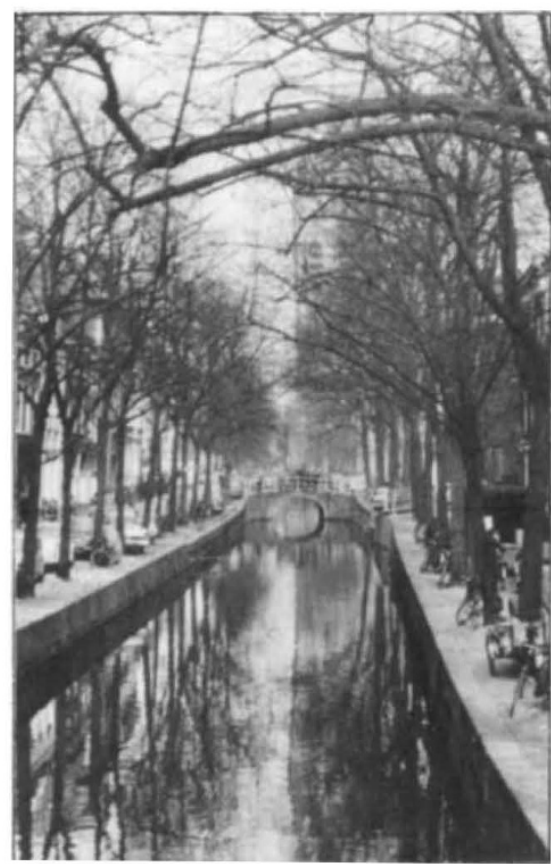

mainly to the institutes' research, and no connection exists with research work elsewhere. The new service has to work as independently as possible and aims at objectivity.

With so many groups working in this area in the Netherlands already, $\mathrm{Mr}$ Trip formed another committee to examine whether the government should subsidise existing activities, particularly of foundations which promoted information based on a particular view on society. The committee considered that critical evaluations of the development of science and technology were necessary, and the minister says in his recommendations that more participatory forms of discussion on science are needed, involving various organisations and groups in society. The committee recommends that government money be used for this, without offering criteria for its disbursement. Thus a 'Science for Citizens' programme which is already carried out on a modest scale in the Netherlands may now grow larger.

- Alternative forms of energy receive much attention in this most densely populated country in the world. After all, nuclear power is not very popular: the construction of three $1,000 \mathrm{MW}$ power plants, and the extension of the ultracentrifuge uranium enrichment plant at Almelo which is part of the tripartite consortium with Britain and Germany, form one of the points of discussion about the formation of a new government Nuclear matters still dominate research, but alternative energies may obtain a foothold. The minister who has energy in his portfolio, $\mathrm{Mr}$ Lubbers of Economic Affairs, is a proponent of nuclear energy on what he calls a modest scale. He has put into service an experimental wind turbine, part of a five-year 15-millionguilder national research programme on wind energy.

The experimental wind turbine, $5 \mathrm{~m}$ in diameter, is of the Darreustype and was built by Fokker-VFW as a spin-off of the rotorblade-production for helicopters. If it is successful a wind turbine $25 \mathrm{~m}$ in diameter will be built as well as a more classic wind-turbine of the same size. $\mathrm{Mr}$ Lubbers sees only a restricted role for wind energy, however, especially with the environmental and countryplanning problems. Experts expect more than $10-20 \%$ of future electricity production to come from the wind.

The problem seems even greater with solar energy, but in fact some 50 houses with solar collectors and other energy saving devices have been built in Holland during the last three years. An ecological group, 'De Kleine Aarde' (the small-scale world), began with a recycling house five years ago and the reseach of a professor at Eindhoven Technical University who lives with his family in a solar house was a stimulus. Philips is doing experiments on 32 houses with collectors; an office building will be constucted with collectors; and this month four houses have been finished in which technical collaborators of the national research organisation will live with their instruments.

The research centre for the building industry foresees the introduction of solar energy devices in houses for space heating and production of warm water from 1980. A national symposium will be held next month on the development of solar energy in the Netherlands.

Casper Schuuring 